\title{
Female pelvic malignancy: spectrum encountered in district hospital: an aid to a general radiologist
}

\author{
D Santosh", A Butler \\ From International Cancer Imaging Society Meeting and 15th Annual Teaching Course (ICIS 2015) \\ London, UK. 5-7 October 2015
}

\section{Purpose}

Initial diagnosis and staging of gynaecological malignancy is often the remit of the local general radiologist. The "incidentaloma" is not infrequently encountered on pelvic imaging undertaken for other indications. It can be dauntradiologist. Cancer Imaging 2015 15(Suppl 1):P45. ing to those without a solid knowledge of the female pelvis.

\section{Learning objectives}

To recognise the spectrum of female pelvic malignancy and appreciate relevant incidental findings.

To identify the pearls and pitfalls of diagnosis, understand important points in staging and restaging disease.

To identify potential complications of both tumour and treatment and discuss imaging strategies in suspected local recurrence.

\section{Content organisation}

We provide an overview of imaging modalities used, review pertinent anatomy and cover the spectrum of malignancy specific to the female pelvis, incorporating common and uncommon tumours. Emphasis is placed on imaging features that are important in treatment planning and evaluating prognosis.

\section{Summary}

This exhibit will enhance the confidence of general radiologist in a district hospital setting when encountering potential female pelvic malignancy at initial diagnosis or when assessing for complications of tumour or treatment in the acute setting.

Published: 2 October 2015

* Correspondence: divyasantosh@gmail.com

Princess Of Wales Hospital, Bridgend, UK

Submit your next manuscript to BioMed Central and take full advantage of:

- Convenient online submission

- Thorough peer review

- No space constraints or color figure charges

- Immediate publication on acceptance

- Inclusion in PubMed, CAS, Scopus and Google Scholar

- Research which is freely available for redistribution
C Biomed Central

(c) 2015 Santosh and Butler This is an Open Access article distributed under the terms of the Creative Commons Attribution License (http://creativecommons.org/licenses/by/4.0), which permits unrestricted use, distribution, and reproduction in any medium, provided the original work is properly cited. The Creative Commons Public Domain Dedication waiver (http://creativecommons.org/ publicdomain/zero/1.0/) applies to the data made available in this article, unless otherwise stated. 